African Crop Science Journal by African Crop Science Society is licensed under a Creative Commons Attribution 3.0 Uganda License. Based on a work at www.ajol.info/ and www.bioline.org.br/cs DOI: http://dx.doi.org/10.4314/acsj.v25i2.4

\title{
FARMERS' PREFERENCES FOR MAIZE ATTRIBUTES IN EASTERN AND WESTERN UGANDA
}

\author{
R. AJAMBO, G. ELEPU, B. BASHAASHA and P. OKORI ${ }^{1}$ \\ Department of Agribusiness and Natural Resource Economics, Makerere University, P. O. Box 7062, \\ Kampala, Uganda \\ ${ }^{1}$ Department of Agricultural Production, Makerere University, P. O. Box 7062, Kampala, Uganda \\ Corresponding author: elepu@ caes.mak.ac.ug, gelepu@gmail.com
}

(Received 25 November, 2015; accepted 10 May, 2017)

\begin{abstract}
Maize (Zea mays L.) is an important staple food crop in Uganda and is emerging as a cash crop for smallholder farmers. Maize has, therefore, been prioritised by the Government of Uganda for continuous improvement through the national agricultural research system, resulting in the release of several improved varieties. However, adoption rates of the improved varieties among farmers remains low possibly due to non-inclusion of important non-yield productive and consumptive attributes in the new maize varieties. This study was conducted to identify and economically evaluate non-yield productive and consumptive attributes that are important to farmers and their influence on the price farmers are willing to pay for seed of varieties that embody those attributes. A survey of 325 randomly selected farmers was conducted in Iganga and Masindi districts in Uganda to identify productive and consumptive attributes they preferred when purchasing seed. Results showed that maize farmers were willing to pay more for seed of short-medium height, short-medium maturity period, and high yielding maize varieties. However, the price farmers were willing to pay for maize seed not only depended on quality attributes, but also on seed market prices and land resource endowment. These results have important implications for policy makers to streamline production, multiplication and distribution of high quality maize seeds in Uganda.
\end{abstract}

Key Words: Adoption, hedonic pricing, seed, smallholder, willingness to pay

\section{RÉSUMÉ}

Le maïs (Zea mays L.) est une culture importante servant d'aliment de base en Ouganda et constitute une culture de rente pour les petits producteurs. Le maïs a, toutefois, été choisi comme une culture prioritaire par le Gouvernement Ougandais pour une amélioration continue à travers le système national de recherhes agricoles, produisant une libération de plusieurs varieties améliorées. Neanmoins, les taux d'adoption de ces variétés par les producteurs demeurent faibles probablement à cause de la non prise en compte d'importants facteurs nonproductifs et de préférences des consommateurs dans le développement des nouvelles variétés. Cette étude a été conduite pour identifier et évaluer économiquement les attributs non-productifs et de consommatiion qui sont importants aux producteurs et leurs influences sur les prix que les producteurs sont disposés à payer pour les grains des variétés comportant ces attributs. Une enquête a été menéé sur 325 producteurs sélectionnés de façon aléatoire dans les districts de Iganga et Masindi pour identifier les attributs de production et de consommation que les producteurs ont préféré quand ils achètent les semences. Les résultats ont montré que les producteurs de maïs sont plus disposés à payer des semences de variétés de maïs de taille courte à moyenne, d'une période de maturité courte à moyenne, et de haut rendement. Néanmoins, le prix que les producteurs étaient disposés à payer pour 
acheter les semences du maïs dépendait non seulement de la qualité des attributs, mais aussi du prix du marché des semences et de dotation en ressources en terres. Ces résultats ont d'importantes implications pour les décideurs politiques leur permettant de rationaliser la production, la multiplication et la distribution des semences de maïs de haute qualité en Ouganda.

Mots Clés: Adoption, méthode des prix hédoniques, petit producteur, propension à payer, semences

\section{INTRODUCTION}

Maize (Zea mays L.) is important in Uganda as a household food and income security crop, as well as a strategic nontraditional export crop to regional markets, such as Kenya and South Sudan (USAID/RATES, 2003; Elepu, 2011). Maize production has been increasing overtime and by 2015 , it exceeded 2.8 million metric tonnes harvested from over 1.1 million ha (UBOS, 2016). Much of the increase in production can be explained by a steady increase in acreage, with little of it attributed to improvements in farmers' productivity that is still low. Over the recent years, national average yields are estimated at about 2.2 $2.5 \mathrm{tha}^{-1}$, against the potential of $4 \mathrm{tha}^{-1}$ (open pollinated maize varieties) and $10 \mathrm{t} \mathrm{ha}^{-1}$ (maize hybrids) with farmer adoption of good agronomic practices (MAAIF, 2015).

Owing to the importance of maize to household and the national economy, Government of Uganda has prioritised it for continuous research for development (R4D) through the national agricultural research system, leading to the release of several improved varieties such as; Kawanda composite, Longe 1 , Longe $2 \mathrm{H}$, Longe $3 \mathrm{H}$, Longe 4, Longe 5 and Longe 6H (MAAIF, 2012). However, the adoption of improved maize varieties is still low and is estimated at only 9\% among farmers in eastern and southern Africa (Langyintuo et al., 2010). This may partly be due to the non-inclusion of important non-yield productive and consumptive quality attributes in the breeding of new maize varieties as noted by Dalton (2004). Therefore, the knowledge of farmers' preferences for quality attributes is important to further inform the maize breeding programme in Uganda.
The objective of this study was to identify and economically evaluate important yield and non-yield attributes of maize to farmers, who also double as consumers in their respective households. With such information available, maize breeders in Uganda can more accurately assess the trade-offs between yield and non yield attributes of maize when developing new varieties. It was hypothesised that farmer preferences for maize attributes such as plant cycle length, plant height, tiller number, grain colour, grain size, pest and disease resistance and drought tolerance affects the price they are willing to pay for maize seed.

\section{METHODOLOGY}

Theoretical framework. Maize seed is a productive input, with heterogeneous attributes or traits. Farmers' subjective valuation of maize attributes was analysed using a hedonic price model. According to Ladd and Martin (1976), inputs are considered as a collection of attributes and that for each input purchased, the price paid by the producer equals the sum of the products of the marginal implicit values of each of the input attributes and their respective marginal yields. That is,

$$
P_{i}=\sum_{j} B_{j} X_{i j}
$$

Where:

$\mathrm{B}_{\mathrm{j}}=$ the marginal implicit value/price of input attribute $j$.

In this study, it was assumed that the attributes of maize seed that influence the price of seed include; plant height, cycle length, grain size, 
grain colour, pest and disease resistance and drought tolerance among others. The semi$\log$ functional form was used because it has been demonstrated to be the best fit model compared to linear and loglinear functional forms in most studies (Brorsen et al., 1988; Matuschke et al. 2007).

The empirical hedonic price model for maize seed in Uganda was, thus specified as follows

$$
\log P_{\mathrm{i}}=\beta_{0}+\beta_{1} X_{1}+\beta_{2} X_{2}+\ldots \ldots \ldots+\beta_{14} X_{13}+\varepsilon
$$

Where:

$\log P_{\mathrm{i}}=$ Logarithm of price in Ugandan shillings that farmers are willing to pay per $\mathrm{kg}$ of seed for their preferred maize variety;

$X_{1}=$ Dummy variable for plant height $(1=$ medium and 0 otherwise, $1=$ short and 0 otherwise, the base attribute being "tall");

$X_{2}=$ Dummy variable for plant cycle length $(1=$ short and 0 otherwise, $1=$ medium and 0 otherwise, the base attribute being "long");

$X_{3}=$ Dummy variable for grain size (1= small and 0 otherwise, $1=$ medium and 0 otherwise for maize, the base attribute being "large");

$X_{4}=$ Dummy variable for grain colour (1 $=$ white and 0 otherwise);

$X_{5}=$ Dummy variable for pest and disease resistance ( $1=$ high and 0 otherwise);

$X_{6}=$ Dummy variable for drought tolerance ( $1=$ high and 0 otherwise);

$X_{7}=$ Dummy variable for gender of respondent $(1=$ female and 0 otherwise);

$X_{8}=\quad$ Logarithm of age of farmer
$X_{9}=$ Farmer level of education $(1=$ none, $2=$ primary, $3=$ secondary, $4=$ tertiary);

$X_{10}=$ Logarithm of maize farming experience (years);

$X_{11}=\quad$ Logarithm of land holding size (ha);

$X_{12}=$ Logarithm of the price farmer paid per $\mathrm{kg}$ of seed in last season's planting (Ush);

$X_{13}=$ Logarithm of perceived maize yield $\left(\mathrm{t} \mathrm{ha} \mathrm{a}^{-1}\right)$;

$\varepsilon=$ Error term; and

$\beta_{0}-\beta_{13}=$ Parameters to be estimated.

This study was conducted in the two districts of Uganda namely, Masindi and Iganga, for maize producer attributes. These districts were purposively selected because of two major reasons; first, they were located in different agro-ecological zones (USAID, 2010) that are both suitable for growing maize and secondly they were major maize producing districts in Uganda (Elepu, 2011). From each district, multistage sampling method was used to purposively select study counties (2), subcounties (2), parishes (2), and villages (2). A total sample of three hundred and twenty-five farmers was then randomly selected to participate in the survey; 161 in Iganga and 164 in Masindi.

A survey was conducted during July December 2009 using a structured questionnaire developed and pre-tested in Iganga district. During the survey, the questionnaire was administered to selected farmers and were designed to first gather information on their socio-economic characteristics of farmer (gender, age, level of education, and household size) and maize production system (farming experience, total land, maize acreage, maize varieties grown, seed sources and prices, productivity, 
production constraints). In the second part of the study, each respondent evaluated different varieties of maize on a hedonic scale of 1-5 ( $1=$ Liked most to $5=$ Dislike most). They were further asked about their most preferred maize variety and to elicit their preferences for maize varieties based on their attributes: grain size (1=small, 2=Medium, 3=large); grain colour ( $1=$ white, $0=$ coloured $)$; plant height $(1=$ short, $2=$ medium, $3=$ tall $)$; cycle length $(1=$ short, $2=$ medium, $3=$ long); pest and disease resistance (1=low, $2=$ medium, $3=$ high $)$ and drought tolerance $(1=$ low, $2=$ medium, $3=$ high). Lastly, they were asked to reveal prices they were willing to pay for their preferred maize seed.

Descriptive statistics, mainly the mean, the $\chi^{2}$ and F- tests were used to explain the economic value that farmers placed on the various quality attributes embodied in maize varieties. Multiple regression analysis techniques were used to estimate the hedonic price function. Ordinary Least Squares (OLS) estimation was undertaken using the STATA 10 computer programme.

\section{RESULTS AND DISCUSSION}

Socio-economic characteristics. Out of a total of 325 respondents, $68 \%$ were men while $32 \%$ were women although Iganga district had a larger proportion of respondents being female (47\%) compared to Masindi district with only $18 \%$ (Table 1). Education level of farmers in both districts was generally low as depicted by a large combined proportion of farmers with no education and those educated up to primary level.

The mean age of farmers interviewed was 38 years and no significant difference in age of farmers existed between study districts. Farmers tended to have larger households in Iganga than Masindi district perhaps depicting the relative sizes of households in study districts $(\mathrm{P}<0.01)$. Similarly, farmers in Iganga had a longer maize growing experience of 15 years than those in Masindi district with 9 years of experience $(\mathrm{P}<0.01)$. However, maize farmers, in both districts were generally smallholders owning average land holdings of 2.0 ha; with 0.6 ha under maize.

TABLE 1. Socio-economic characteristics of maize farmers in Iganga and Masindi districts, Uganda

\begin{tabular}{lcccc}
\hline Characteristic & Iganga $(\mathrm{n}=161)$ & Masindi $(\mathrm{n}=164)$ & Total (N=325) & $\chi^{2}$ or F-statistic \\
\hline Gender (\%) & & & & \\
Male & 53 & 82 & 68 & $29.733^{* * * *}$ \\
Female & 47 & 18 & 32 & \\
Level of education (\%) & & & & \\
None & 15 & 8 & 11 & \\
Primary & 42 & 70 & 56 & $24.652^{* * * *}$ \\
Secondary & 40 & 21 & 31 & \\
Tertiary & 3 & 1 & 2 & \\
& 40 & 37 & 38 & 3.849 \\
Age (years) & 9 & 6 & 8 & $29.652^{* * *}$ \\
Household size & 1.6 & 2.4 & 2 & 6.462 \\
Land size (ha) & 0.56 & 9 & 0.6 & 3.497 \\
Maize acreage (ha) & 15 & & 12 & $32.753^{* * * *}$ \\
Maize growing experience (years) & & & & \\
\hline
\end{tabular}

$* * * 1 \%$ level of significance; $* * 5 \%$ level of significance 
Maize varieties grown. Results indicated that some respondents grew more than one variety of maize, and local varieties were still popular, especially in Iganga where more than half of the respondents reported growing it (Table 2). Longe 5 was the commonly grown improved variety in both districts, although a higher proportion $(51 \%)$ of farmers in Iganga compared to $32 \%$ in Masindi. Longe $6 \mathrm{H}$ and
Longe 4 were also important improved varieties grown, but only in Masindi. A small proportion (3\%) of farmers also grew Kenyan hybrids in both districts.

Farmers' preferences for existing maize varieties. Figure 1 shows more than a half (69\%) of the respondent farmers ranked Longe 5 as "Like most" while; $75 \%$ of farmers ranked

TABLE 2. Maize varieties grown by farmers in Iganga and Masindi (percent) in Uganda

\begin{tabular}{lcccc}
\hline Variety & Iganga $(\mathrm{n}=161)$ & Masindi $(\mathrm{n}=164)$ & Total $(\mathrm{N}=325)$ & $\chi^{2}$ \\
\hline Longe 1 & 9 & 0.0 & 5 & $15.924 * * *$ \\
Longe $2 \mathrm{H}$ & 5 & 2 & 3 & 2.417 \\
Longe $3 \mathrm{H}$ & 2 & 0.0 & 1 & 3.066 \\
Longe 4 & 12 & 23 & 17 & $6.729 * * *$ \\
Longe 5 & 51 & 32 & 41 & $12.094 * * *$ \\
Longe 6H & 9 & 23 & 16 & $1.976 * * *$ \\
Longe 7H & 1 & 0.0 & 0.3 & $26.495 * * *$ \\
Local & 51 & 23 & 37 & 0.488 \\
Kenya hybrids & 2 & 3 & 3 & 0.46 \\
\hline
\end{tabular}

$* * * 1 \%$ level of significance; $* * 5 \%$ level of significance

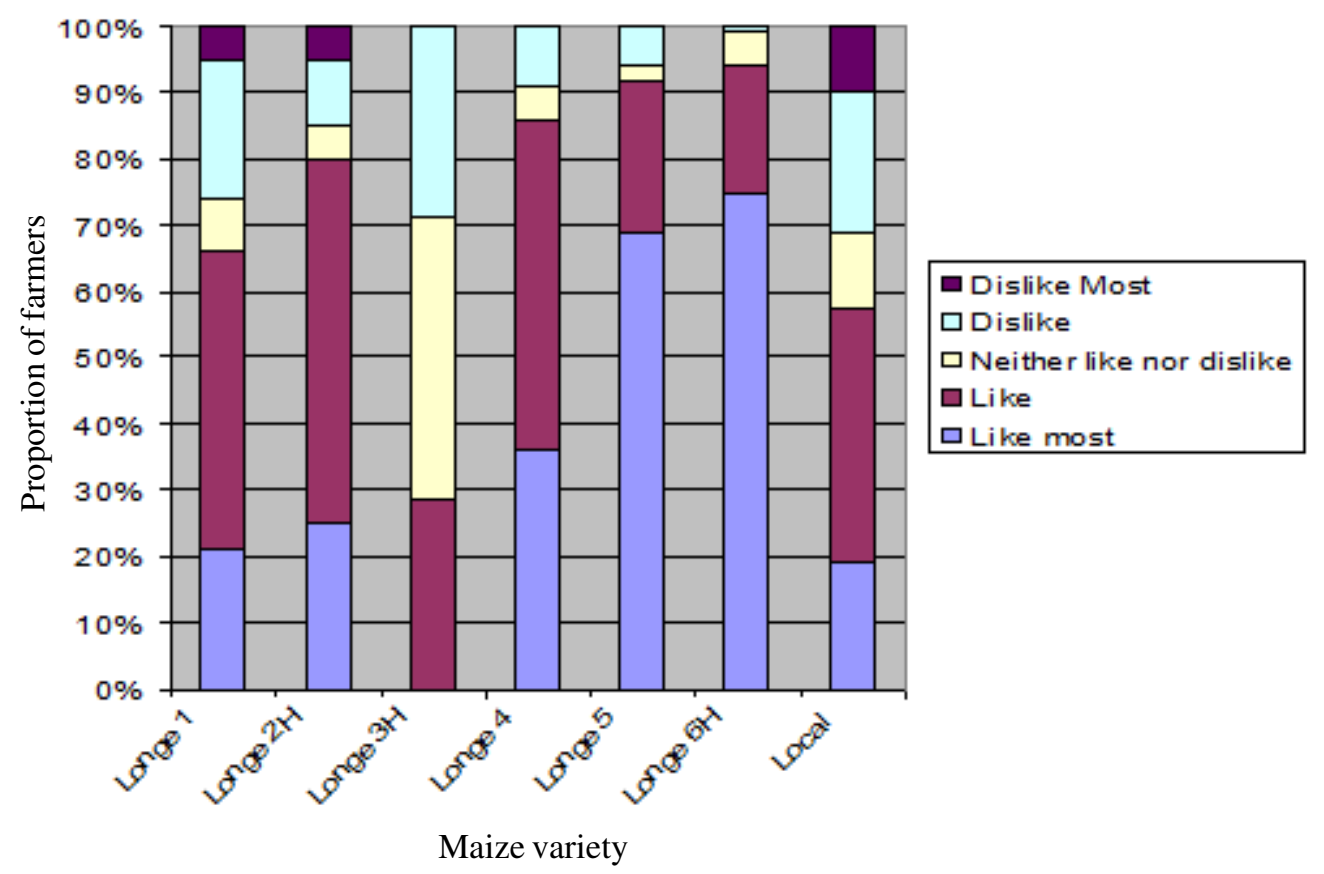

Figure 1. Farmers' hedonic ranking of maize varieties in Uganda. 
Longe $6 \mathrm{H}$ as "Like most" on a hedonic scale. The major reasons for farmers growing these varieties were that; (i) they matured in a short time, (ii) they were resistant to pests and diseases, (iii) made tasty local bread known as "posho"; and (iv) their seed was readily available. A smaller proportion of respondent farmers $(38 \%)$ ranked the local varieties as "Like" for their tasty "posho;" while $21 \%$ ranked local varieties as "Dislike" because local varieties were perceived as low yielding. Other varieties that were ranked "Dislike" were Longe 3H (27\%), Longe 1 (20\%) and Longe $2 \mathrm{H}(10 \%)$. Among the reasons given for ranking these varieties "Dislike" was that they possessed low pest and disease resistance, particularly Longe $2 \mathrm{H}$ which was reported to be prone to cob rots.

Farmers' most preferred maize varieties by district are shown in Table 3. The $\chi^{2}$-test was highly significant, showing that farmers preferred to grow different maize varieties in study districts. Farmers in Iganga preferred Longe 5 (52\%) and local varieties (22\%); while farmers in Masindi preferred Longe 6H (49\%) and Longe $5(28 \%)$. The other variety that was also preferred for production in both Iganga and Masindi was Longe 4.

Farmer preference for maize seed attributes. Farmers considered plant height, plant cycle, grain size, pest and disease resistance and drought tolerance as important attributes in a maize variety (Table 4).
A small proportion (6\%) of farmers in both districts preferred maize of short heights while majority (88\%) preferred varieties of medium height (Table 4). However, a small proportion (7\%) of farmers preferred tall maize varieties, which were mainly local varieties. Most farmers claimed that tall maize varieties were difficult to harvest and were also prone to logging. In tandem with the Agricultural Sector Strategic Plan (ASSP), there is, therefore, need to focus on production, multiplication and distribution of various maize varieties to meet heterogeneous farmers' needs and thus, enhance their uptake of improved varieties, productivity, and production of maize in study districts and Uganda as a whole (MAAIF, 2015).

More than half $(55 \%)$ of the respondents preferred maize varieties that matured in a short period of time, less than three and half months (Table 4). This was attributed to the fact that varieties that matured in a short time tended to escape severe droughts, which have been recurrent in recent years. A significant proportion of farmers (44\%) preferred maize varieties that matured in medium time period or "normal" time of about three and half months. In contrast, only a small proportion (1\%) of the respondents preferred late maturing varieties, that is, varieties that took more than 3.5 months to mature. It is no doubt, maize production in the study districts takes place in two seasons allowing for only short and medium maize varieties to perform better

TABLE 3. Farmers' most preferred maize varieties (percent) in two districts in Uganda

\begin{tabular}{lccc}
\hline Variety & Iganga $(\mathrm{n}=161)$ & Masindi $(\mathrm{n}=164)$ & Total $(\mathrm{N}=325)$ \\
\hline Longe 1 & 2 & 0.0 & 1 \\
Longe $2 \mathrm{H}$ & 2 & 0.0 & 1 \\
Longe 4 & 9 & 12 & 11 \\
Longe 5 & 52 & 28 & 40 \\
Longe $6 \mathrm{H}$ & 8 & 49 & 29 \\
Longe $7 \mathrm{H}$ & 1 & 0.0 & 0.0 \\
Local & 21 & 7 & 14 \\
Kenya hybrid & 5 & 4 & 4 \\
\hline
\end{tabular}

Chi-square $=86.204 * * *$ 
TABLE 4. Farmer preferences for maize seed attributes (percent) in two districts in Uganda

\begin{tabular}{|c|c|c|c|c|}
\hline Attribute & Iganga $(n=161)$ & Masindi (n=164) & Total $(\mathrm{N}=325)$ & $\chi^{2}$ \\
\hline \multicolumn{5}{|c|}{ Plant height } \\
\hline Short & 10 & 2 & 6 & \\
\hline Medium & 81 & 94 & 88 & $13.805 * * *$ \\
\hline Tall & 9 & 4 & 7 & \\
\hline \multicolumn{5}{|c|}{ Plant cycle } \\
\hline Short & 58 & 52 & 55 & \\
\hline Medium & 41 & 47 & 44 & 1.426 \\
\hline Long & 1 & 1 & 1 & \\
\hline \multicolumn{5}{|c|}{ Grain size } \\
\hline Short & 4 & 7 & 5 & \\
\hline Medium & 39 & 62 & 51 & $24.563 * * *$ \\
\hline Large & 58 & 31 & 44 & \\
\hline \multicolumn{5}{|c|}{ Grain colour } \\
\hline White & 97 & 99 & 98 & 2.793 \\
\hline Coloured & 3 & 1 & 2 & \\
\hline \multicolumn{5}{|c|}{ Pest and disease resistance } \\
\hline Medium & 18 & 2 & 10 & $21.598 * * *$ \\
\hline High & 82 & 98 & 90 & \\
\hline \multicolumn{5}{|c|}{ Drought tolerance } \\
\hline Medium & 15 & 2 & 9 & $16.041 * * *$ \\
\hline High & 85 & 98 & 91 & \\
\hline
\end{tabular}

*** $1 \%$ level of significance

(USAID/RATES, 2003). Perhaps this explains why farmers preferred short-medium maturing maize varieties in both districts.

Majority $(90 \%)$ of farmers preferred maize varieties with high pest and disease, and drought tolerance (Table 4). This suggests that drought, pests and diseases were the major constraints to maize production in both districts. It can also be argued that due to recurrent climate change impacts, these factors might become even more severe in the future in studied maize growing districts. Maize production is expected to decline in Uganda due to climate change impacts in future (Thornton et al., 2010). Using the 2005-07 average as a base, Thornton et al. (2010) project that maize production might drop by $2.2 \%$ in 2030 and by $8.6 \%$ in 2050 in Uganda.
Hence, drought resistant maize varieties that will take-up more heat units and more adaptation to climate change need to be developed and distributed to farmers.

More than half $(51 \%)$ of farmers preferred maize with medium grain size; yet $44 \%$ preferred varieties of large grain size that they said led to heavy grain weight (Table 4). However, a small proportion $(5 \%)$ of farmers preferred maize varieties with small grain size since these varieties made tasty bread or posho.

Regarding maize grain colour, nearly all (98\%) farmers in both districts liked white kernelled maize perhaps because of their high demand in the market (Elepu, 2011). However, this study also revealed that as one moves down the maize value chain, grain quality is highly downplayed by traders and processors. 
Maize grain traders bulk commodity maize without due regard to grain size and colour, leading to lack of price premiums for high quality maize in the market. Small-scale millers, who are major industry players, also prefer small grain maize since it is easier to process using their inefficient, locally fabricated hammer mills. Hence, there is need for sensitisation and promotion of use of maize quality standards among all value chain actors.

Farmer willingness to pay for seed of preferred maize varieties. In general, farmers were willing to pay a price ranging from Ush 200 - 6,000 (US\$ 0.10 - 3.12) per $\mathrm{kg}$ for seed of their most preferred maize variety. These prices were comparable to the market price of maize seed and grain at the time of the survey. Local maize grain were bought at Ush 200 - 250 (US\$ 0.12 - 0.13) per kg; while seed of improved maize varieties ranged from Ush 2,000 (US\$1.04) per $\mathrm{kg}$ for Longe 5 and 4 to Ush 6,000 (US\$ 3.12) per $\mathrm{kg}$ for Longe $6 \mathrm{H}$ and some of the Kenya hybrids. Increasing the efficiency of the maize seed distribution system in Uganda could thus lead to enhanced access to high quality seeds by farmers whose usage rate of improved seeds sourced from the market is still as low as $11 \%$ (Okoboi, 2010).

Factors affecting farmer willingness to pay for maize seed attributes. Table 5 presents the estimated parameters and corresponding p-values for maize quality and socio-economic variables used in this study. The adjusted $\mathrm{R}^{2}$ (goodness of fit measure) of the log linear model was estimated to be 0.369 , meaning that about $37 \%$ variation in price that farmers were willing to pay for maize seed of their preferred variety was explained by the estimated model.

The dummy variable for short plant height and yield of maize had a positive and significant impact on the price farmers were willing to pay for maize seed (Table 5). Farmers were willing to pay $32.5 \%$ more for seed of varieties of short height at maturity compared to those considered to be tall. In addition, farmers were willing to pay $1.9 \%$ more for seed, with a $1 \%$ increase in yield of maize (Table 5). These results are consistent with those from a study by Matuschke et al. (2007), who found that due to the higher yield potential of hybrid wheat, farmers in India were willing to pay for hybrid wheat seed even though farmer willingness to pay was $15 \%$ below current market prices. In another study, farmers in Nigeria and Benin were also found to prefer improved over local rice varieties because of higher yields (Horna et al., 2007).

The dummy variable for plant cycle length had a significant and negative sign (Table 5). This means that farmers were discounting plant cycle length and were willing to pay 56.5 $62.5 \%$ less for short to medium plant cycle length compared to the base category - long cycle length. This result could be due to the fact that a significant proportion (37\%) of farmers grew local varieties, which took long to mature; that is, more than three and a half months. These results are in direct contrast with Hintze et al. (2003), who reported that maize farmers in Honduras highly valued the short maturity attribute in maize varieties. More education may be needed to enlighten Ugandan maize farmers on the usefulness of growing maize varieties with shorter maturity periods.

The coefficient associated with price of seed in the last season was positive and significant (Table 5, $\mathrm{P}<0.05$ ). This means that holding all other factors constant, farmers were willing to pay $14 \%$ more for seed with a $1 \%$ increase in last season's seed price. This may be because when price of seed is high, it is perceived by farmers to be high yielding. For example, at the time of the study, the price of Longe $6 \mathrm{H}$ ranged between Ush 3,500 - 4,500 (US\$ 1.82 - 2.34) per kg; while the price of Longe 5 ranged between Ush 2,000 - 3,000 (US\$ 1.04 - 1.56) per kg; and, Longe 6H was perceived by farmers to be higher yielding than Longe 5. Streamlining production and distribution of high quality maize seed is hence important owing to the existence of fake and 
TABLE 5. Regression results for farmer willingness to pay for maize seed in Uganda

\begin{tabular}{|c|c|c|c|c|}
\hline Variable name & Coefficient & Standard error & t-statistic & P-value \\
\hline Intercept & $2.705^{* * *}$ & 0.403 & 6.71 & 0.000 \\
\hline \multicolumn{5}{|l|}{ Plant height } \\
\hline Short & $0.325 * * *$ & 0.104 & 3.11 & 0.002 \\
\hline Medium & 0.139 & 0.139 & 1.70 & 0.091 \\
\hline \multicolumn{5}{|l|}{ Plant cycle length } \\
\hline Short & $-0.565^{* * *}$ & 0.176 & -3.20 & 0.002 \\
\hline Medium & $-0.625^{* * *}$ & 0.177 & -3.53 & 0.001 \\
\hline \multicolumn{5}{|l|}{ Grain size } \\
\hline Small & -0.125 & 0.089 & -1.41 & 0.161 \\
\hline Medium & -0.001 & 0.037 & -0.40 & 0.972 \\
\hline Grain colour (white) & -0.208 & 0.130 & -1.60 & 0.112 \\
\hline Pest and disease resistance (high) & 0.035 & 0.104 & 0.34 & 0.733 \\
\hline Drought tolerance (high) & 0.120 & 0.104 & 1.16 & 0.249 \\
\hline Gender (female) & 0.009 & 0.037 & 0.24 & 0.813 \\
\hline Log of farmers' age & -0.098 & 0.160 & -0.61 & 0.514 \\
\hline Level of farmer education (years) & 0.043 & 0.026 & 1.64 & 0.103 \\
\hline Log of maize farming experience & -0.068 & 0.057 & -1.20 & 0.231 \\
\hline Log of land holding size & $0.163^{* * *}$ & 0.045 & 3.56 & 0.000 \\
\hline Log of price of seed in last season & $0.138 * *$ & 0.053 & 2.61 & 0.010 \\
\hline Log of perceived maize yield & $0.176^{* *}$ & 0.074 & 2.37 & 0.019 \\
\hline $\begin{array}{l}\text { Number of observations } \\
\text { Adjusted } R^{2}=0.369\end{array}$ & 325 & & & \\
\hline
\end{tabular}

$* * * 1 \%$ level of significance, $* * 5 \%$ level of significance, $* 10 \%$ level of significance

non-certified seeds on the market (MAAIF, 2015).

Other maize seed attributes, namely: pest and disease resistance, drought tolerance, grain size and grain colour had no significant influence on the price farmers that paid for maize seed (Table 5). Though all these maize attributes were rated highly by nearly all farmers, there was lack of variation in their preferences to be captured in statistical analysis. For example, $98 \%$ of the farmers preferred maize varieties with white grain colour (Table 2).

Regarding the influence of socio-economic characteristics of farmers on their willingness to pay for maize seed, only amount of land owned had a significant effect. Other socio- economic variables, namely: gender, age, maize growing experience and level of education of farmer did not have significant effect on farmers' willingness to pay for improved maize seed (Table 5). The coefficient associated with size of land had a positive sign and was highly significant $(\mathrm{P}<0.01)$. This means that holding other factors constant, farmers were willing to pay $16 \%$ more for seed with a $1 \%$ increase in land holding size. This may be because farmers with more land were commerciallyoriented and grew improved maize varieties. Increased improved input usage has been found to be associated with commercialising maize farmers in Uganda (Okoboi, 2010). Thus, promotion of commercialisation of maize 
production will lead to increased demand for improved seed in Uganda.

\section{CONCLUSION}

Farmers in Uganda are willing to pay more for seed of short-medium height, short-medium maturity period, and high yielding maize varieties. Farmers consider high yield in a maize variety an important criterion, especially if the variety is newly released due to potential higher gains from grain sale. However, the price farmers are willing to pay for maize seed not only depends on quality attributes, but also on seed market prices and land resource endowment. These results have important implications for policy makers to focus national breeding programmes on production of maize varieties with superior productive attributes and ensure an efficient seed distribution system for the benefit of all segments of farmers. Moreover, different maize varieties need to be bred targeted to different agro-ecological zones and, farmers need to be involved in the development of new maize varieties through participatory breeding and selection.

\section{ACKNOWLEDGMENT}

This study was supported with funding from the Millennium Science Initiative - Unlocking the Potential of Maize and Sorghum project (MSI-UPMAS) of Makerere University.

\section{REFERENCES}

Brorsen, B.W., Grant, W.R. and Rister, M.E. 1988. Some effects of rice quality on rough rice prices. Southern Journal of Agricultural Economics 20(1):131-140.

Dalton, T.J. 2004. A hedonic model of rice traits: Economic values from farmers in West Africa. Agricultural Economics 31:149-159.

Elepu, G. 2011. Baseline analysis and assessment of the value chain of maize in Uganda. A Final Report. Common Market in Eastern and Southern Africa (COMESA) Centre, Lusaka, Zambia.

Hintze, L.H., Renkow, M. and Sain, G. 2003. Variety attributes, transaction costs and maize adoption in Honduras. Agricultural Economics 29:307-317.

Horna, J.D., Smale, M. and von Oppen, M. 2007. Farmers' willingness to pay for seedrelated information: Rice varieties in Nigeria and Benin. Journal of Environment and Development Economics 12:799-825.

Ladd, W.G. and Martin, B.M. 1976. Prices and demand for input attributes. American Journal of Agricultural Economics 58:2130.

Langyintuo, A.S., Mwangi, W., Diallo, A.O., MacRobert, J., Dixon, J. and Bänziger, M. 2010. Challenges of the maize seed industry in eastern and southern Africa: A compelling case for private-public intervention to promote growth. Food Policy 35:323-331.

MAAIF. 2015. Agriculture Sector Strategic Plan: 2015/16 - 2019/20. Ministry of Agriculture, Animal Industry and Fisheries, Entebbe, Uganda.

MAAIF. 2012. Operationalization of the non ATAAS Component of the Development Strategy and Investment Plan: Analytical Report (Grains). Ministry of Agriculture, Animal Industry and Fisheries, Entebbe, Uganda.

Matuschke, I., Mishara, R.R. and Quaim, M. 2007. Adoption and impact of hybrid wheat in India. World Development 35:14221435.

UBOS. 2016. Statistical abstract. Uganda Bureau of Statistics, Ministry of Finance, Planning and Economic Development, Kampala, Uganda.

Okoboi, G. 2010. Improved inputs use and productivity in Uganda's maize sub-sector. Research Series No. 69, Economic Policy Research Center (EPRC), Kampala, Uganda.

Thornton, P.K., Jones, P.G., Alagarswamy, G., Andresen, J. and Herrero M. 2010. 
Adapting to climate change: Agricultural system and household impacts in East Africa. Agricultural Systems 103(2): 73-82

USAID/RATES. 2003. Maize market assessment and baseline survey for Uganda. Report. United States Agency for
International Development/ Regional Agricultural Trade Expansion Support, RATES Centre, Nairobi, Kenya.

USAID. 2010. Livelihood mapping and zoning exercise: Uganda. United States Agency for International Development. 